\title{
To study analyze maternal serum alpha-fetoprotein as a biomarker of placental adherence in low lying placenta
}

\author{
Pooja Verma*, Kavita N. Singh, Vineeta Ghanghoriya
}

\begin{abstract}
Department of Obstetrics and Gynecology, Netaji Subhash Chandra Bose Medical College and Hospital, Jabalpur, Madhya Pradesh, India
\end{abstract}

Received: 15 April 2016

Accepted: 09 May 2016

\author{
*Correspondence: \\ Dr. Pooja Verma, \\ E-mail: pvermagmc@gmail.com
}

Copyright: (c) the author(s), publisher and licensee Medip Academy. This is an open-access article distributed under the terms of the Creative Commons Attribution Non-Commercial License, which permits unrestricted non-commercial use, distribution, and reproduction in any medium, provided the original work is properly cited.

\section{ABSTRACT}

Background: To study the place of Maternal Serum Alfa Feto Protein (MSAFP) as a biomarker of placental adherence in low lying placenta, and to study maternal outcome in the study group.

Methods: This is a prospective observational study analyzing the conditions and the data of 90 cases with low lying placenta in a tertiary care hospital. The analysis was done for the association of MSAFP with MRI, perinatal and maternal outcome.

Results: The level of MSAFP was found higher in 14 out of 15 cases (93.3\%) of placenta previa with placental adherence. There was significant surgical intervention (80\%) and increased maternal morbidity $(68.8 \%)$ in the study group with placental adherence and raised MSAFP respectively.

Conclusions: MSAFP is an important biomarker for prognostication of placental adherence in low lying placenta.

Keywords: Low lying placenta, Placental adherence, MSAFP

\section{INTRODUCTION}

Antepartum hemorrhage forms one of the most dangerous and devastating group of disorders in obstetrics. Placenta previa occurs in approximately 1 in 300 deliveries. ${ }^{1}$ At least $5 \%$ of such pregnancies have associated placental invasion (placenta accreta), which can necessitate hysterectomy. $^{2}$

The independent risk factor for placenta praevia is a previous caesarean section. The risk increases with the number of caesarean sections performed. The incidence of placenta accreta is $3 \%$ in women with placenta previa and one previous cesarean section. The risk continues to increase with each additional cesarean section up to $67 \%$ in women with a placenta previa and five or more cesarean sections. ${ }^{3}$

\section{Other risk factors include $e^{4-6}$}

History of myomectomy, vigourous curettage resulting in asherman syndrome, submucous leiomyomas , previous uterine thermal ablation, uterine artery embolization and maternal age greater than 35 years old.

Once bleeding develops in cases of placenta previa it is likely to complicate the remainder of the pregnancy. Finding markers for complications in women with previa might help obstetricians to recognize placenta previa early and transport them to the major referral hospital, thereby decreasing the maternal and fetal morbidity and mortality.

It has been hypothesized that a disruption in the maternal-fetal interface allows increased trasnfer of AFP into the maternal circulation. ${ }^{7}$ Others suggest that elevated AFP levels are a surrogate marker for abnormal implantation and placental malfunction that are the underlying pathologic mechanisms for many adverse obstetric outcomes. ${ }^{8,9}$ Furthermore, an increased risk for abnormal placental adherence (i.e. placenta accreta/increta/percreta) also has been demonstrated in women with an elevated maternal serum AFP level, especially in the presence of a placenta previa. ${ }^{10,11}$ 
In view of these findings, this study was undertaken to evaluate the abnormal levels of maternal serum alfa feto protein (MSAFP) as biomarker of abnormal placentation and placental adherence in the second and third trimester of pregnancy.

\section{METHODS}

This was a prospective observational study analyzing the condition and the data of 90 cases with low lying placenta admitted to the department of Obstetrics and Gynecology, Netaji Subhash Chandra Bose - Medical College Hospital Jabalpur, from $1^{\text {st }}$ October 2014 to $30^{\text {th }}$ September 2015 after ethical clearance from ethical institute committee of Netaji Subhash Chandra Bose Medical College Hospital Jabalpur.

\section{Inclusion criteria}

All pregnant women with clinical or USG diagnosis of placenta previa or low lying placenta.

\section{Exclusion criteria}

All pregnant women with placenta in upper segment.

All pregnant women with other causes of $1^{\text {st }}, 2^{\text {nd }}$ or $3^{\text {rd }}$ trimester bleeding diagnosed as abortion, abruptio placentae, ectopic pregnancy, Hydatiform, mole, local causes of vaginal bleeding, polyp, or foreign body etc.

After taking history and informed consent, study group were counselled about the importance of the test to identify the risk factors for placental adherence. The venous blood sample was drawn and the level of MSAFP was determined by ELISA method, and result of MSAFP level was co-related with USG/MRI findings. In this study cases were classified as per William's Classification of placenta previa. $^{12}$ Descriptive statistical methods were used to calculate the variables for continuous data and categorical data. The chi-square test for proportion was used for the test of significance to find association between categorical variables. The critical levels of significance of the result were considered at 0.05 levels, i.e. $\mathrm{P}<0.05$ was considered significant.

\section{RESULTS}

In present study, out of 90 cases 37 (41.1\%) had total placenta previa, 29 cases $(32.2 \%)$ had marginal placenta previa, 14 cases $(15.6 \%)$ had partial placenta previa and 10 cases $(11.1 \%)$ had low lying placenta.

Placental adherence was absent in $75(83.3 \%)$ cases, 12 $(13.3 \%)$ cases had placenta accreta, $2(2.2 \%)$ cases had placenta increta and $1(1.1 \%)$ case had placenta percreta.

MRI was done in 7 cases, out of which $4(57.1 \%)$ cases had no evidence of placental adherence while $3(42.8 \%)$ cases revealed placental adherence. MSAFP was raised in all 3 cases which revealed placental adherence and in 1 case with no evidence of placental adherence $(\mathrm{p}=0.006)$ (Table 1).

Table 1: Association between MSAFP and MRI.

\begin{tabular}{|c|c|c|c|c|c|}
\hline \multirow[b]{2}{*}{ MSAFP } & \multicolumn{4}{|c|}{ MRI n (\%) } & \multirow{2}{*}{$\begin{array}{l}P \\
\text { value }\end{array}$} \\
\hline & Normal & Abnormal & $\begin{array}{l}\text { Not } \\
\text { done }\end{array}$ & Total & \\
\hline Normal & $3(4.3)$ & $0(0)$ & $\begin{array}{l}66 \\
(95.7)\end{array}$ & $\begin{array}{l}69 \\
(100)\end{array}$ & \multirow{2}{*}{0.006} \\
\hline Raised & $1(4.8)$ & $3(14.3)$ & $\begin{array}{l}17 \\
(81)\end{array}$ & $\begin{array}{l}21 \\
(100)\end{array}$ & \\
\hline Total & $4(4.4)$ & $3(3.3)$ & $\begin{array}{l}83 \\
(92.2)\end{array}$ & $\begin{array}{l}90 \\
(100)\end{array}$ & \\
\hline
\end{tabular}

Table 2: Distribution of cases according to maternal outcome.

\begin{tabular}{|lll|}
\hline Maternal outcome & Frequency & $\%$ \\
\hline Normal delivery & 9 & 10 \\
Preterm delivery & 12 & 13.3 \\
\hline Caesarean section (CS) & 35 & 38.9 \\
\hline $\begin{array}{l}\text { CS with uterine artery or } \\
\text { internal iliac artery ligation }\end{array}$ & 31 & 34.4 \\
\hline Caesarean hysterectomy & 3 & 3.3 \\
\hline Total & 90 & 100 \\
\hline
\end{tabular}

Table 3: Association between MSAFP and maternal delivery outcome.

\begin{tabular}{|c|c|c|c|c|c|c|c|c|c|}
\hline \multirow[b]{2}{*}{ MSAFP } & \multicolumn{8}{|c|}{ Maternal outcome n (\%) } & \multirow{2}{*}{$\begin{array}{l}\text { P-value } \\
0.000\end{array}$} \\
\hline & $\begin{array}{l}\text { Normal } \\
\text { delivery }\end{array}$ & $\begin{array}{l}\text { Caesarean } \\
\text { section- no } \\
\text { intervention }\end{array}$ & $\begin{array}{l}\text { Caesarean } \\
\text { Section- } \\
\text { Unilateral } \\
\text { uterine } \\
\text { artery } \\
\text { ligation }\end{array}$ & $\begin{array}{l}\text { Caesarean } \\
\text { Section- } \\
\text { Bilateral } \\
\text { uterine } \\
\text { artery } \\
\text { ligation }\end{array}$ & $\begin{array}{l}\text { Caesarean } \\
\text { Section- } \\
\text { Internal } \\
\text { iliac artery } \\
\text { ligation }\end{array}$ & $\begin{array}{l}\text { Preterm } \\
\text { delivery }\end{array}$ & $\begin{array}{l}\text { Caesarean } \\
\text { hysterectomy }\end{array}$ & Total & \\
\hline Normal & $8(11.6)$ & $34(49.3)$ & $9(13)$ & $8(11.6)$ & $0(0)$ & $10(14.5)$ & $0(0)$ & $69(100)$ & \\
\hline Raised & $1(4.8)$ & $1(4.8)$ & $0(0)$ & $12(57.1)$ & $2(9.5)$ & $2(9.5)$ & $3(14.3)$ & $21(100)$ & \\
\hline Total & $9(10)$ & $35(38.9)$ & $9(10)$ & $20(22.2)$ & $2(2.2)$ & $12(13.3)$ & $3(3.3)$ & $90(100)$ & \\
\hline
\end{tabular}


Table 4: Association between MSAFP and placenta adherence.

\begin{tabular}{|c|c|c|c|c|c|c|}
\hline \multirow{2}{*}{ MSAFP } & \multicolumn{5}{|c|}{ Placenta adherence $\mathbf{n}(\%)$} & \multirow[t]{2}{*}{ P value } \\
\hline & Not adhered & Placenta accreta & Placenta increta & Placenta percreta & Total & \\
\hline Normal & $68(98.6)$ & $1(1.4)$ & $0(0)$ & $0(0)$ & $69(100)$ & \multirow{2}{*}{0.000} \\
\hline Raised & $7(33.3)$ & $11(52.4)$ & $2(9.5)$ & $1(4.8)$ & $21(100)$ & \\
\hline Total & $75(83.3)$ & $12(13.3)$ & $2(2.2)$ & $1(1.1)$ & $90(100)$ & \\
\hline
\end{tabular}

Table 5: Association between MSAFP and maternal and perinatal morbidity.

\begin{tabular}{|c|c|c|c|c|c|}
\hline \multirow[t]{2}{*}{ MSAFP } & \multicolumn{4}{|c|}{ Morbidity n (\%) } & \multirow[t]{2}{*}{$\begin{array}{l}\mathbf{P} \\
\text { value }\end{array}$} \\
\hline & Mother & Perinatal & None & Total & \\
\hline Normal & $7(10.1)$ & $\begin{array}{l}13 \\
(18.8)\end{array}$ & $\begin{array}{l}49 \\
(71)\end{array}$ & $\begin{array}{l}69 \\
(100)\end{array}$ & \multirow[b]{2}{*}{0.000} \\
\hline Raised & $15(71.4)$ & $3(14.3)$ & $\begin{array}{l}3 \\
(14.3)\end{array}$ & $\begin{array}{l}21 \\
(100)\end{array}$ & \\
\hline Total & $22(24.4)$ & $\begin{array}{l}16 \\
(17.8)\end{array}$ & $\begin{array}{l}52 \\
(57.8)\end{array}$ & $\begin{array}{l}90 \\
(100)\end{array}$ & \\
\hline
\end{tabular}

Table 2 shows that out of 90,9 (10\%) cases had normal vaginal delivery, $12(13.3 \%)$ cases had preterm delivery, $35(38.9 \%)$ cases had undergone caesarean section, 31 $(34.4 \%)$ cases had caesarean section with either uterine artery or internal iliac artery ligation, and $3(3.3 \%)$ cases had caesarean hysterectomy.

Table 6: Association between maternal morbidity and placental adherence.

\begin{tabular}{|c|c|c|c|c|}
\hline \multirow{2}{*}{$\begin{array}{l}\text { Placental } \\
\text { adherence }\end{array}$} & \multicolumn{4}{|c|}{ Maternal morbidity (\%) } \\
\hline & Present & Absent & Total & $\mathrm{p}$ \\
\hline Not adhered & $10(13)$ & $65(87)$ & $75(100)$ & \multirow{5}{*}{0.00} \\
\hline Placenta accreta & $9(75)$ & $3(25)$ & $12(100)$ & \\
\hline Placenta increta & $2(100)$ & $0(0)$ & $2(100)$ & \\
\hline $\begin{array}{l}\text { Placenta } \\
\text { percreta }\end{array}$ & $1(100)$ & $0(0)$ & $1(100)$ & \\
\hline Total & $22(24)$ & $68(76)$ & $90(100)$ & \\
\hline
\end{tabular}

12 out of $20(60 \%)$ cases of caesarean section with bilateral uterine artery ligation, all 3 cases (100\%) of caesarean hysterectomy and both cases (100\%) of caesarean section with internal iliac artery ligation had MSAFP significantly raised with $\mathrm{p}=0.00$ (Table 3 ).

MSAFP > 2.5MoM in 11 out of 12 cases $(91.6 \%)$ of placenta accreta, both cases of placenta increta $(100 \%)$ and the only case of placenta percreta $(100 \%)(\mathrm{p}=0.00)$ (Table 4).

MSAFP was raised in $68.18 \%$ (15 out of 22) cases associated with maternal morbidity, as compared to $18.7 \%$ ( 3 out of 16 ) cases associated with fetal morbidity or $5.7 \%$ (3 out of 52) who had neither maternal nor fetal morbidity $(\mathrm{p}=0.00)$ (Table 5$)$.

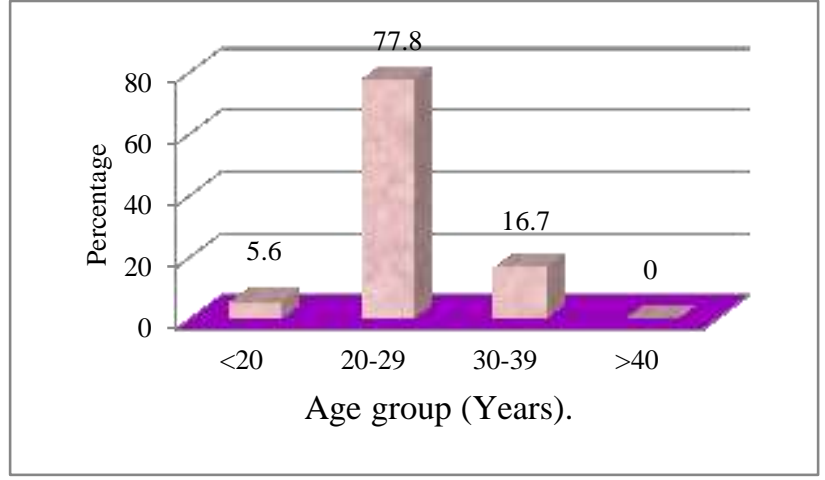

Figure 1: Distribution of cases according to age.

Maternal morbidity was present in 12 out of $15(80 \%)$ cases of placental adherence (Table 6).

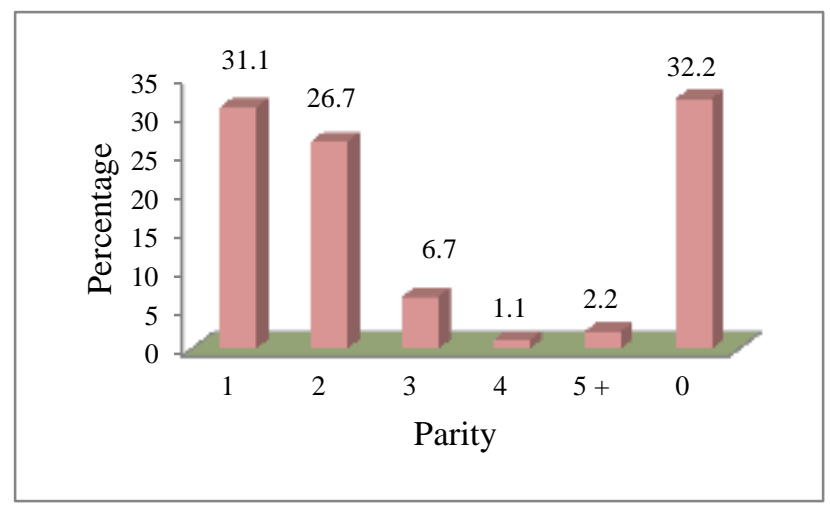

Figure 2: Distribution of cases according to parity.

\section{DISCUSSION}

In present study $77.8 \%$ of cases belonged to age group 20-29 years, followed by $16.7 \%$ for age group of 30-39 years, and $5.6 \%$ for $<20$ years of age. In women $>35$ years, the risk of previa is $1.1 \%$ as compared to $0.5 \%$ for women $<35$ years (Figure 1$).^{13}$

In study group $32.2 \%$ patients were nulliparous, $31.1 \%$ were para one and $26.7 \%$ were para two. The remaining $10 \%$ of the cases included $6.7 \%$ para three, $1.1 \%$ para four, and $2.2 \%$ para five and more. Babinszki and colleagues reported that $2.2 \%$ incidence in women para five or greater was increased significantly as compared with women with lower parity (Figure 2). ${ }^{14}$ 


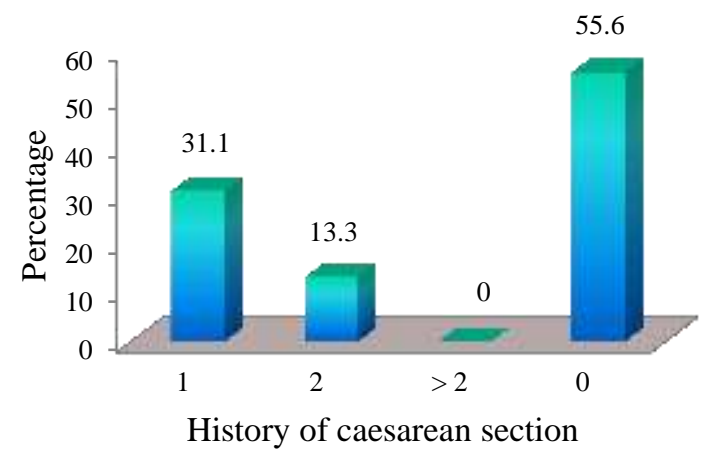

Figure 3: Distribution of cases according to history of previous caesarean section.

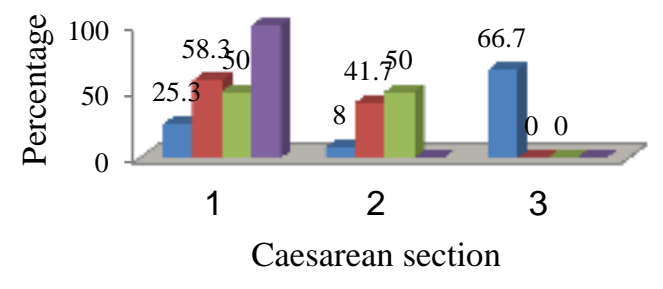

- Placenta increta Placenta increta 2

- Placenta increta 3 - Placenta percreta

\section{Figure 4: Association between caesarean section and placental adherence.}

In the present study advancing maternal age $(16.7 \%>=30$ years) and increasing parity (10\% para three and more) were independent risk factors for placenta previa. However, since women with higher parity are likely to be older, it is possible that advanced maternal age and increased parity are not independent risk factors. This combined effect of age and gravidity on the risk of placenta previa was demonstrated in a large populationbased, cohort study of singleton births from the USA. ${ }^{15}$ This study showed that the risk of placenta previa was not independent of maternal age and parity, but rather that both factors exerted a joint influence on placenta previa risk. In other words, increasing maternal age and increasing parity conferred the greatest risk of placenta previa compared with that of primigravida women aged $<20$ years.

The present study showed that $55.6 \%$ (50) of the study group had no history of previous caesarean section, $31.1 \%$ (28) had history of one previous caesarean section and $13.3 \%$ (12) had history of two previous caesarean sections. In a study done by Lala $\mathrm{ABH}$ et al the incidence of placenta previa is $2 \%$ after one previous caesarean section, $4.1 \%$ after two and $22 \%$ after three previous caesarean sections (Figure 3). ${ }^{16}$

In the study performed significant association of placental adherence was seen in cases who had undergone previous one caesarian section (32\% - 9 out of 28 cases) or previous two caesarian section (50\% - 6 out of 12) in the past, as compared to cases who had not undergone any previous caesarian sections in whom no cases of adherence was seen. No significant association was seen with dilatation and curettage or any other scar of uterus as of myomectomy. Silver et al gave the increasing incidence of placenta accreta in cases with increasing number of prior uterine incision (Figure 4). ${ }^{3}$

In the present study MSAFP was elevated in 12 out of 20 $(60 \%)$ cases of caesarean section with bilateral uterine artery ligation, all 3 cases of caesarean hysterectomy and both cases of caesarean section with internal iliac artery ligation. The result was statistically significant (Table 3). Zelop C et al performed a study in which $45 \%$ cases of caesarean hysterectomy due to placenta accreta/increta/percreta had elevated MSAFP levels. ${ }^{10}$ Kupferminc et al performed a similar study and gave the same result. ${ }^{11}$ Another study done by Katherine et al also placed high levels of MSAFP in pregnancy as a surrogate marker for abnormal placentation as well as placental adherence and adverse maternal outcome. ${ }^{17}$

MSAFP was found normal in 68 out of $75(90.6 \%)$ cases where the placenta was not adhered. It was raised in 11 out of $12(91.6 \%)$ cases of placenta accreta, in both the cases $(100 \%)$ of placenta increta and in one case of placenta percreta (100\%). The association was statistically significant (Table 4). McDuffie RS et al gave a case report where placenta percreta was associated with elevated MSAFP in second trimester. ${ }^{18}$ TAI-HO HUNG et al performed a study which included 10672 antenatal patients, and they finally concluded that placenta previa with raised MSAFP and age > 35 years are the risk factors for placenta accreta. ${ }^{19}$ Oyelese $\mathrm{Y}$ et al performed another study on patients with placenta previa and found that MSAFP was raised in $45 \%$ of the cases of placenta accreta. $^{20}$ Gagnon A et al reviewed the obstetrical outcomes associated with abnormally elevated MSAFP and found that second or third trimester placenta previa and unexplained elevation of MSAFP have increased association for placental adherence and planning of delivery, technique and location should be done accordingly. ${ }^{21}$

Significant association was seen between raised MSAFP and maternal morbidity (Table 5). Butler et al performed the study on 107 antenatal patients with placenta previa, out of which 14 had elevated levels of MSAFP and these were the patients who required prolonged hospitalization, ICU monitoring, multiple blood transfusions and even had preterm deliveries. ${ }^{22}$ Thus concluded that raised MSAFP is associated with increased maternal and fetal morbidity.

In present study $80 \%$ cases of placental adherence were associated with maternal morbidity. The association was statistically significant (Table 6). In cases of placental adherence correction and treatment of hemorrhage often requires massive blood transfusion, ICU admission, 
interventional radiological procedures and hysterectomy which increases the maternal morbidity. ${ }^{23}$

\section{CONCLUSION}

Maternal serum alpha feto protein is an important biomarker for prognostication of placental adherence in low lying placenta, so that the patient is referred to tertiary care centre for further management. It was observed that surgical interventions were more in the study group. Maternal morbidity was observed in $80 \%$. There was no maternal mortality.

\section{ACKNOWLEDGEMENT}

Authors would like thanks to Dr Professor R. Chauhan, (MS; FICMCH), Professor and Head, Department of Obstetrics and Gynecology, Netaji Subhash Chandra Bose Medical College and Hospital. Jabalpur, MP, India.

Funding: No funding sources

Conflict of interest: None declared

Ethical approval: The study was approved by the Institutional Ethics Committee

\section{REFERENCES}

1. Martin JA, Hamilton B E, Sutton PD et al. Birth final data for 2003. National vital statistics report. 2005;54(2).

2. Cunningham FG, MacDonald PC, Gant NF, Leveno KJ, Gilstrap LC, Hankins GDV, et al. Obstetrical hemorrhage. In: Williams Obstetrics, 20th ed. Appleton \& Lange: Stamford. 1997:755-6.

3. Silver, Robert M, Landon Mark B. Maternal morbidity associated with multiple repeat cesarean delivery. Obstet Gynecol. 2006;107(6):1226-32.

4. Al-Serehi A, Mhoyan A, Brown M, Benirschke K, Hull A, Pretorius DH. Placenta accreta: an association with fibroids and Asherman syndrome. J Ultrasound Med. 2008;27:1623-8.

5. Hamar BD, Wolff EF, Kodaman PH, Marcovici I. Premature rupture of membranes, placenta increta, and hysterectomy in a pregnancy following endometrial ablation. J Perinatol. 2006;26:135-7.

6. Pron G, Mocarski E, Bennett J, Vilos G, Common A, Vanderburgh L. Pregnancy after uterine artery embolization for leiomyomata: the Ontario multicenter trial. Ontario UFE Collaborative Group. Obstet Gynecol. 2005;105:67-76.

7. Berkeley AS, Killackey MA, Cedarqvist LL. Elevated maternal serum alpha-fetoprotein levels associated with breakdown in fetal-maternalplacental barrier. Am J Obstet Gynecol. 1983;146:85.

8. Morssink LP, de Wolf BT, Kornman LH. The relation between serum markers in the second trimester and placental pathology: a study on extremely small for gestational age fetuses. BJOG. 1996;103:779-83.

9. Chandra S, Scott H, Dodds L, et al. elevated maternal serum $\alpha$-fetoprotein and/or human chorionic gonadotropin and the risk of adverse outcomes. Am J Obstet Gynecol. 2003;189:775-81.

10. Zelop C, Nadel A, Frigoletto FD Jr. Placenta accreta/precreta/ increta: a cause of elevated maternal serum alpha-fetoprotein. Obstet Gynecol. 1992;80:693-4.

11. Kupferminc MJ, Tamura RK, Wigton TR. Placenta accreta is associated with elevated maternal serum alpha-fetoprotein. Obstet Gynecol. 1993;82:266-9.

12. Williams. Textbook of Obstetrics. F. Gary Cunningham. Chpt. 35 - Obstetrical Hemorrhage. 23rd edition United States of America. McGrawHill; 2010:769

13. Cleary-Goldman J. Impact of maternal age on obstetric outcome. Obstet Gynecol. 2005;105:983.

14. Babinszki A, Kerenyi T. Perinatal outcome in grand and great grand multiparity. Effects of parity on obstetric risk factors.Am J Obstet Gynecol. 1999;181:669.

15. Ananth CV, Demissie K, Smulian JC. Placentanprevia in singleton and twin births in the United States, 1989 through 1998. A comparison of risk factor profiles and associated conditions. Am J Obstet Gynecol. 2003a;188:275.

16. Lala ABH, Rutherford JM. Massive or recurrent ante partum haemorrhage. Current Obstetrics and Gynaecology. 2002;12:226-30.

17. Goetzinger KR, Odibo AO. Screening for abnormal placentation and adverse pregnancy outcomes with maternal serum biomarkers in the second trimester. John Wiley and sons ltd. 2014;10(1002):4370.

18. Mcduffie RS Harkness L, Mcvay RM. Mid trimester hemoperitoneum caused by placenta percreta in association with elevated MSAFP. American journal of obstetrics \$ gynecology.1994;171(2):565-6.

19. Hung T, Shau W, Hsieh C, Chiu T. Risk factors for placenta accreta. Obstet Gynecol. 1999;93:545-50.

20. Oyelese Y, Smulian JC. Placenta Previa. Obstet Gynecol. 2006;10(4):927.

21. Gagnon A, Wilson RD, Audibert F. Obstetrical complications associated with abnormal maternal serum markers analytes. Journal of Obstetrics and Gynecology Canada. 2008;30(10):918-49.

22. Butler EL, Ronald MM. Association between Maternal Serum Alpha-Fetoprotein and Adverse Outcomes in Pregnancies With Placenta Previa. Obstetrics and Gynecology. 2001;97(1):35-8.

23. Silver RM, Barbour KD. Plaenta Accreta Spectrum. Clinical Review articles. Obst and Gynecol. Clinics of North America. 2015;42(2):381-402.

Cite this article as: Verma $\mathrm{P}$, Singh $\mathrm{KN}$, Ghanghoriya V. To study analyze maternal serum alpha-fetoprotein as a biomarker of placental adherence in low lying placenta. Int J Reprod Contracept Obstet Gynecol 2016;5:1959-63. 